\author{
Part of Journal of Research of National Bureau of Standards, Volume 33, \\ August 1944
}

\title{
EXTENT OF HYDROLYSIS OF STARCHES BY AMYLASES IN THE PRESENCE AND ABSENCE OF YEASTS ${ }^{1}$
}

\author{
By William Ward Pigman
}

\begin{abstract}
The extent of enzymic conversion of corn starch, waxy maize starch, and potato amylose into materials fermentable by yeasts was studied for a number of different types of amylases. When the amylases are allowed to act on the starch substances, complete conversion to fermentable material may take place when the yeasts are allowed to act in the presence of the enzymes but not when the amylases and yeast act separately. The amylases that are capable of bringing about complete conversion are the cereal $\alpha$-amylases and the fungal amylases. Certain bacterial amylases, pancreatic amylases, and the cereal $\beta$-amylases convert starch only partially to fermentable substances in the presence of yeasts. The experiments described in the present paper were carried out at starch concentrations comparable to those employed in industrial grain-alcohol processes.

With the notable exception of the malt amylases and the $\beta$-amylases, all of the enzyme preparations studied are capable of synthesizing unfermentable substances from maltose and presumably from starch hydrolysis products. For certain of the enzyme preparations, this synthesizing action provides an explanation for the lack of complete conversion of the starches to fermentable materials. For other enzymes, however, other explanations are more probable. The nature of the actions of the amylases are considered in relation to the structures of the starch substances.

Improved procedures are given for the preparation of soybean $\beta$-amylase and of potato amylose. Methods are described for bringing starches into solution without preliminary gel formation.
\end{abstract}

\section{CONTENTS}

I. Introduction

II. Action of malt amylases on different types of starches

III. Action of several types of amylase preparations on corn and waxy maize starches and potato amylose

IV. Synthesizing action of amylases on maltose

V. Application of bacterial and pancreatic emulsions for the liquefaction of corn starch..... 112

VI. Action of amylase preparations on the unfermentable residual dextrins_ 114

VII. Nature of action and classification of the amylases

VIII. Experimental procedure.

1. Materials used.

(a) Enzyme preparations (emulsins)

(b) Starches

2. Procedures

1 This paper, with Mary Grace Blair as coauthor, was presented before the Division of Sugar Chemistry and Technology of the American Chemical Society at Cleveland, Ohio, April 1944. 


\section{INTRODUCTION}

The action of amylases on starches is a fundamental process involved in many industrial operations, such as the preparation of alcoholic beverages and alcohol from grains and of dextrins for sizes and adhesives. Much experimental work has been carried out with the purpose of elucidating the nature of the action of the amylases. However, in most of this earlier work, the course of the enzymic hydrolysis has been followed by the measurement of the reducing power (usually calculated as maltose) during the reaction. In the experiments described in the present paper, the extent of hydrolysis brought about by the action of various amylase preparations on starch is measured by the amount of material present that is fermentable by baker's yeast. The determination of fermentable sugars, in many cases, appears to be of more value than reducing-sugar determinations, since the determination of the total reducing power of mixtures of dextrose, maltose, oligosaccharides, and dextrins obviously has little quantitative significance. ${ }^{2}$

The principal purpose of the present investigation is the determination of the ability of amylase preparations from different sources to bring about the conversion of starches to fermentable sugars. This study derives its importance from the necessity of knowing which types of amylases are the most suitable for application to the preparation of alcohol from starchy materials. In the course of obtaining the information necessary for the solution of the principal problem, considerable data has been obtained concerning the action of different types of amylases on starches.

In general, the experiments reported in the present paper were set up to simulate the commercial practice in the fermentation industries as far as possible. Thus, although most earlier investigators employed dilute solutions, the starch concentrations used in the experiments discussed below are of the order of 10 to 13 percent. In order to bring the starches into solution, the following general procedure was employed.

A stirred starch suspension was heated to $74^{\circ}$ to $76^{\circ} \mathrm{C}$ and kept at this temperature for 10 to 15 minutes. The amylase preparation was added and allowed to act at $70^{\circ}$ to $74^{\circ} \mathrm{C}$ for 10 to 15 minutes. (For the less heat-stable amylases, lower temperatures were employed in this stage.) Then, the stirred solution was heated at $100^{\circ} \mathrm{C}$ for 30 minutes, cooled to $45^{\circ}$ to $50^{\circ} \mathrm{C}$, and the final portion of the enzyme preparation was added. After several hours, the solution was allowed to cool to $30^{\circ}$ C. Baker's yeast was added to the solution, and fermentation was continued for 5 days. The alcohol produced was determined by distillation and measurement of the specific gravity of the distillate. From the fermentation efficiency, as determined from blank experiments with maltose and dextrose and from the amount of alcohol

2 The ideal method would permit the determination of the various constituents selectively, but the problem is ver difficult. However, selective methods are available. (See for example: A. S. Schultz, R. A. Fisher, L. Atkin, and C. N. Frey, Ind. Eng. Chem. Anal. Ed. 15, 496 (1943); M. Somogyi, J. Biol. Chem. 119, 741 (1937). Although the fermentation method is capable of quantitative expression, it is more timeconsuming than reducing-sugar determinations. Also the question arises as to the nature of the products that are fermented. It is well known that dextrose and maltose are fermentable by ordinary yeasts. However the nature of other fermentable products is less certain. One of the possible constituents of such products is "isomaltose", which may be identical with 6 - $\alpha$-glucosyl-glucose, although its constitution has not been completely established; it may be a mixture of several products and is usually reported not to be fermented by yeasts. On the other hand Myrbäck (J. prakt. Chem. 162, 29 (1943) reports that mal. totriose (presumably 4 -glucose $4^{\prime}$-( $\alpha$-glucosyl)- $\alpha$-glucoside ) is fermentable. 
formed, the amount of fermentable sugars produced from the starch can be calculated. Under good conditions, the probable error of the method should not exceed \pm 1 percent.

\section{ACTION OF MALT AMYLASES ON DIFFERENT TYPES OF STARCHES}

As a result of preliminary experiments, a laboratory procedure was developed whereby complete conversion of corn starch by barley malt to fermentable substances is achieved. The best conditions for this purpose are summarized above and given in more detail in the experimental part. As illustrated in table 1, wheat, potato, and waxy maize starches also are converted completely to fermentable sugars by the malt amylases in the presence of yeasts. The amount of alcohol obtained from Lintner soluble starch seems significantly smaller than that obtained from the equivalent weight of dextrose, and it appears that this acid-modified starch may contain a small amount of material that resists the action of the amylases.

In spite of their obvious importance to the alcohol industry, there are but few reports in the literature of experiments of the above type. Hopkins, Cope, and Green ${ }^{3}$ were able to bring about only 85.9 percent production of fermentable sugars by the action of barley diastase and yeasts on soluble starches. However, their results are not in particular disagreement with those in table 1 , since the barley diastase is principally $\beta$-amylase, whereas the germinated barley (malt) contains other enzymes.

TABLE 1.-Action of malt on several starches in the presence of yeast

\begin{tabular}{|c|c|c|}
\hline Starch & $\begin{array}{l}\text { Alcohol from } \\
24.96 \mathrm{~g} \text { of dry } \\
\text { starch } a\end{array}$ & $\begin{array}{l}\text { Conversion } \\
\text { efficiency (\%) } \\
\text { of theoretical) }\end{array}$ \\
\hline $\begin{array}{l}\text { Corn } \\
\text { Wheat } \\
\text { Potato } \\
\text { Waxy maize } \\
\text { Lintner soluble } \\
\text { Theory }\end{array}$ & $\begin{array}{r}g \\
12.78 \\
12.81 \\
12.71 \\
12.54 \\
12.07 \\
b(12.54)\end{array}$ & $\begin{array}{r}101.9 \\
102.1 \\
101.3 \\
100.0 \\
96.2 \\
(100)\end{array}$ \\
\hline
\end{tabular}

- Corrected for malt blank.

b For 88.5-percent fermentation efficiency, as determined from blank experiments with dextrose and with maltose and calculated from the Gay-Lussac equation.

\section{ACTION OF SEVERAL TYPES OF AMYLASE PREPARA- TIONS ON CORN AND WAXY MAIZE STARCHES AND POTATO AMYLOSE}

According to the present conception of the structure of the starch substances, most starches are mixtures of two types of components: amyloses which consist of long unbranched chains of glucose residues connected through alpha 1,4'-glucosidic linkages; and amylopectin which consists of similar chains with branches. Corn starch, for example, contains 21 percent of amylose and presumably 79 percent of amylopectin. ${ }^{4}$ In the present series of experiments, corn starch was

3 R. H. Hopkins, G. F. Cope, and J. W. Green, J. Inst. Brewing 39, 487 (1933)。

F. L. Bates, D. French, and R. E. Rundle, J. Am. Chem. Soc. 65, 142 (1943). 
selected for study because it is one of the most important starches from the standpoint of the alcohol and starch industries and because its composition is fairly representative of the cereal starches in general. In addition, it was decided to study the behavior of waxy maize starch and potato amylose as representative of the individual starch fractions; it has been demonstrated, ${ }^{4}$ that waxy maize starch is free of amylose and consists solely of the amylopectin constituent. The amylose was prepared from potatoes by the butanol-precipitation procedure of Schoch. ${ }^{5}$

These starch substances were treated with amylase preparations from different sources by the method summarized in the introduction. In one set of experiments, the fermentation was carried out in the presence of the active amylases, and in a second set the amylases were destroyed before the yeast was added. The results obtained are summarized in table 2 .

TABLE 2.-Action of amylase preparaitions on several types of starch substances

\begin{tabular}{|c|c|c|c|c|c|}
\hline \multirow{3}{*}{ Amylase source } & \multicolumn{5}{|c|}{$\begin{array}{l}\text { Degree of conversion to fermentable substances } \\
\text { (percentage of theoretical) }\end{array}$} \\
\hline & \multicolumn{2}{|c|}{ Corn starch } & \multicolumn{2}{|c|}{$\begin{array}{l}\text { Waxy maize starch } \\
\text { (amylopectin) }\end{array}$} & \multirow{2}{*}{$\begin{array}{c}\begin{array}{c}\text { Potato } \\
\text { amylose }\end{array} \\
\begin{array}{c}\text { Amylases } \\
\text { present } \\
\text { during fer- } \\
\text { mentation }\end{array}\end{array}$} \\
\hline & $\begin{array}{l}\text { Amylases } \\
\text { present } \\
\text { during fer- } \\
\text { mentation }\end{array}$ & $\begin{array}{l}\text { Amylases } \\
\text { absent } \\
\text { during fer- } \\
\text { mentation }\end{array}$ & $\begin{array}{l}\text { Amylases } \\
\text { present } \\
\text { during fer- } \\
\text { mentation }\end{array}$ & $\begin{array}{l}\text { Amylases } \\
\text { absent } \\
\text { during fer- } \\
\text { mentation }\end{array}$ & \\
\hline Barley malt ..... & 103 & 89 & 100 & 90 & \\
\hline Malt extract & & 88 & & 91 & $(100)$ \\
\hline Malt $\alpha$-amylase & 100 & 87 & & 89 & \\
\hline 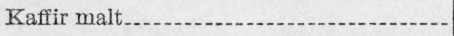 & a 99 & $\begin{array}{c}\text { a } 87 \\
\text { b }(66)\end{array}$ & a 99 & $\begin{array}{l}\text { s } 90 \\
\text { b }(80)\end{array}$ & \\
\hline Aspergillus ory zae-A & 98 & $\begin{array}{l}73 \\
81\end{array}$ & $\begin{array}{r}98 \\
100\end{array}$ & $\begin{array}{l}(80) \\
77 \\
69\end{array}$ & \\
\hline A. oryzae-C & 98 & 85 & & & (n- \\
\hline A, niger & 97 & 77 & & & \\
\hline Whole pancreas & 77 & 47 & 77 & 49 & 74 \\
\hline Bacillus mesentericus & 55 & 53 & 57 & 47 & 71 \\
\hline Wheat $\beta$-amylase & 69 & 64 & 70 & 59 & 96 \\
\hline 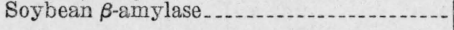 & 64 & & 68 & 65 & \\
\hline
\end{tabular}

s In the presence of added calcium chloride.

$\mathrm{b}$ In the absence of added calcium chloride.

- The results reported for the amylose are to be considered as only of a preliminary nature. Since the amylase contained some insoluble material, the value obtained by the action of malt extract was taken as indicating 100-percent hydrolysis. In addition, the results are less accurate than those obtained from the corn and waxy maize starches, because one-fourth of the usual quantities were used in the experiments. It is hoped that additional experiments of this character can be carried out with purified amyloses at a later time.

The results in table 2 show that only certain amylase preparations are capable of converting starches completely to fermentable substances in the presence of yeasts. Such preparations are those containing the so-called cereal $\alpha$-amylases (barley and kaffir malts) and the Aspergillus amylases. Barley malt and the malt extract are known to contain not only $\alpha$-amylases but also $\beta$-amylases. The malt $\alpha$-amylase preparation was made by the heat-inactivation procedure of Ohlsson, ${ }^{6}$ which is said to inactivate the $\beta$-amylase component (probably incompletely). According to Kneen, ${ }^{7}$ kaffir malt (germi-

${ }^{5}$ T. J. Schoch, J. Am. Chem. Soc. 64, 2957 (1942); E. J. Wilson, Jr., T. J. Schoch and C. S. Hudson, J. Am. Chem. Soc. 65, 1382 (1943).

6 E. Ohlsson, Z. physiol. Chem. 189, 17 (1930).

7 E. Kneen, Wallerstein Comm. 6, 101 (1943). The sample used was supplied through the courtesy of

Dr. Kneen, whose cooperation in this matter is gratefully acknowledged. 
nated Sorghum vulgare) contains an $\alpha$-amylase and no $\beta$-amylase. If either the heat-treated barley malt or the kaffir malt is free of $\beta$-amylases, it appears that the $\beta$-amylases are not essential for the saccharifiration of starches to fermentable substances. It is also clear from these results that the Lintner method, ${ }^{8 a}$ which mainly evaluates the $\beta$-amylase activity, is not sufficient for the determination of the amylase activity of commercial diastases. The measurement ${ }^{8 \mathrm{~b}}$ of characteristics of the $\alpha$-amylase action such as the liquefying property or the dextrinizing property would seem to be of more value than the measurement of the saccharifying property as performed in the Lintner method.

The amylases in pancreas and Bacillus mesentericus emulsins ${ }^{9}$ do not appear to be able to break down starches completely to fermentable cugars in the presence of yeasts. However, for these enzymes the problem is complicated because the enzymic action proceeds best near neutrality ( $\mathrm{pH} 6$ to 8 ) where the fermentation of maltose by yeasts takes place with difficulty if at all. Numerous experiments were carried out in which the $\mathrm{pH}$ during the fermentation period was held between 5 and 6 , and the results shown in table 2 seem fairly reproducible. It appears that these emulsins are incapable of completely converting starches to fermentable sugars in the presence of yeasts, at least from a practical standpoint. The reasons for this discrepancy and its practical significance will be considered in more detail in section IV.

According to the results outlined in table 2, wheat and soybean $\beta$-amylases are unable to break down starches completely to fermentable sugars. Amylose, however, appears to be practically quantitatively hydrolyzed. These results are in agreement with earlier studies of the action of the $\beta$-amylases. Measurements of the reducing power of the products obtained by extended action of $\beta$-amylases on whole starches have shown that the reaction stops at a degree of hydrolysis of about 60 percent. ${ }^{10}$ The fermentable sugar is maltose, and the unfermentable material is a dextrin with a high molecular weight. The straight chain amylose, however, is reported to be completely hydrolyzed to maltose by the $\beta$-amylases. ${ }^{11}$

For the soybean $\beta$-amylase (see table 2 ), there seems to be very little difference between the hydrolytic action in the presence and in the absence of yeasts. In the case of the wheat enzyme, however, there seems to be a significantly greater production of fermentable sugar when the reaction takes place in the presence of yeasts. The origin of this difference in action is unclear, but it seems probable that it may be due to the presence of small amounts of an $\alpha$-amylase in the wheat preparation.

The results obtained for the $\beta$-amylases are important in relation to the proposed use of wheat extracts as diastatic agents for the conversion of wheats to fermentable substances. Wheat extracts are

\footnotetext{
8a For a discussion of the various modifications of the Lintner method, see, C. A. Browne and F. W. Zerban, Sugar Analysis, p. 1154 (John Wiley \& Sons, Inc., New York, N. Y. 1941).

$8 \mathrm{~b}$ See: R. M. Sandstedt, E. Kneen, and M. J. Blish, Cereal Chem. 16, 712 (1939); W. R. Johnston and S. Jozsa, J. Am. Chem. Soc. 57, 701 (1935).

"As previously explained, the term "emulsin" is used in a general sense in place of "enzyme preparation," and refers to the crude or partially purified enzyme preparations from plants or animals. See, W. W. Pigman, J. Research NBS 30, 159 (1943) RP1526 (footnote 2). B. Helferich and F. Vorsatz, Z. physiol. Chem. ₹37, 254 (1935).

${ }_{10}$ See, for example, J. Blom, A. Bak and B. Braae, Z. physiol. Chem. 241, 273 (1936); M. Samec and M. Bline, Kolloid-Beihefte 49, 93 (1939).

${ }_{11}$ A. R. Ling and D. R. Nanji, J. Chem. Soc. 127, 629 (1925); K. H. Meyer, W. Brentano and P. Bernfeld, Helv. Chim. Acta 23, 845 (1940).
} 


\section{Journal of Research of the National Bureau of Standards}

known ${ }^{12}$ to be low in $\alpha$-amylase (liquefying) activity as compared to malted grains.

Although the wheat extracts are rich in $\beta$-amylase, the data of table 2 indicate that they are unsuitable for industrial starch conversions. If used, it would be necessary to supplement their action by the addition of malt or fungal amylases. Since wheat extracts have a high saccharifying power, it is again obvious that the Lintner determinations have little value for the evaluation of diastatic activities for the fermentation industries.

When fermentation of the products of amylase action takes place in the absence of amylases, complete conversion to fermentable sugars does not result (see table 2). Additional experiments, described and discussed in more detail in section IV, indicate that there is no single reason for the lack of complete hydrolysis in the absence of yeasts. For the fungal, bacterial, and pancreatic emulsins, incomplete hydrolysis is probably to be ascribed to the synthesis of unfermentable material during the period of diastatic action. For the $\beta$-amylase preparations, a residual high molecular weight dextrin is formed which is unattacked by both the $\beta$-amylases and the yeasts. Finally, for the cereal $\alpha$-amylase preparations, it appears that an equilibrium may be established during the amylase action and that about 10 percent of unfermentable material is in the equilibrium solution.

The preparations from barley and kaffir malt carry the conversion of starches to 90 ( 87 to 91 ) percent of the theoretical quantity of fermentable sugar. This figure is appreciably higher than the value usually accepted for the extent of conversion as measured by reducing sugar determinations. (See footnote 10, page 109). In contrast to earlier results, there also appears to be no appreciable increase in the degree of conversion for the preparations which are known to contain large amounts of $\beta$-amylases (barley malt). As mentioned in the introduction, much of this difference between the results obtained from fermentable sugar and reducing sugar determinations is undoubtedly to be ascribed to the lack of quantitative significance of the reducingsugar method when applied indiscriminately to mixtures of maltose, dextrins, and dextrose, such as are known to be obtained as the result of the action of the $\alpha$-amylases. It should be noted, however, that recent work of Hopkins and Kulka ${ }^{13}$ shows that malt $\alpha$-amylase converts starches to reducing sugar (as maltose) to an extent of about 90 percent.

Although corn starch is reported to contain about 23 percent of the amylose and waxy maize starch to consist solely of amylopectin, the extent of action of the amylases on the two materials appears (within the experimental error) to be the same. If the amylopectin fractions of the two types of starches are identical, it would be expected that the corn starch would exhibit higher conversion by $\beta$-amylases to fermentable material because of its amylose content. However, the identity of the two amylopectin fractions has never been demonstrated.

In the first experiments carried out with the kaffir malt, complete conversion to fermentable substances was not achieved. It was found that the presence of calcium ions ${ }^{14}$ was necessary for complete sac-

12 H. C. Gore and S. Józsa, Ind. Eng. Chem. 24, 102 (1932).

18 R. H. Hopkins and D. Kulka, Wallerstein Comm. 5, 115 (1942).

14 One-half gram of calcium chloride was used in these experiments; this quantity corresponds to a concentration of about $0.2 \mathrm{~g} / 100 \mathrm{ml}$. 
charification. It is well known ${ }^{15}$ that calcium salts protect certain enzymes from inactivation; and it would appear that the calcium salts probably function in this manner in the experiments carried out with the kaffir malt. The influence of salts (calcium and also sodium chloride) was investigated in connection with the action of the enzymes which were not capable of completely breaking down the starch to fermentable substances, but the kaffir malt was the only preparation exhibiting any appreciable effect on the degree of conversion.

\section{SYNTHESIZING ACTION OF AMYLASES ON MALTOSE}

In the early stages of the present investigation the action of mixtures of several amylase-containing emulsins on starches was studied for the purpose of decreasing the amount of unfermentable material produced in the absence of yeasts. Surprisingly enough, it was observed that frequently less fermentable material was produced by the joint action of two amylase preparations than occurred when either acted alone. Since the most probable explanation for this behavior appeared to be that unfermentable material was being synthesized from the products of diastatic hydrolysis, experiments were set up in order to investigate the action of the enzyme preparations on dextrose and maltose.

For the study of the synthesizing action of amylase preparations on maltose and dextrose, two types of experiments were carried out with 15 -percent solutions of the sugars. In one group of experiments, the enzymes were allowed to act on the buffered sugar solutions for several days at $57^{\circ} \mathrm{C}$. The solutions were heated to destroy the enzymes, and the amount of fermentable sugar present was determined by fermentation with yeast and measurement of the amount of alcohol formed. As blank experiments, the same procedure was followed, but additional quantities of the enzyme preparations were added with the yeasts so that the enzymes were present during the fermentation period. The results obtained are summarized in table 3.

None of the enzyme preparations studied exhibited any synthetic action on dextrose solutions. With the probable exception of the

TABLE 3.-Synthetic action of amylase preparations on maltose and dextrose

\begin{tabular}{|c|c|c|c|c|}
\hline \multirow{3}{*}{ Amylase source } & \multicolumn{4}{|c|}{ Fermentable material remaining after enzyme treatment } \\
\hline & \multicolumn{2}{|c|}{ Dextrose } & \multicolumn{2}{|c|}{ Maltose } \\
\hline & $\begin{array}{l}\text { Enzymes } \\
\text { present } \\
\text { during } \\
\text { fermentation }\end{array}$ & $\begin{array}{c}\text { Enzymes } \\
\text { absent } \\
\text { during } \\
\text { fermentation }\end{array}$ & $\begin{array}{l}\text { Enzymes } \\
\text { present } \\
\text { during } \\
\text { fermentation }\end{array}$ & $\begin{array}{c}\text { Enzymes } \\
\text { absent } \\
\text { during } \\
\text { fermentation }\end{array}$ \\
\hline Malt_........ & Percent & Percent & Percent $_{97}$ & ${ }_{\text {Percent }}{ }_{98}$ \\
\hline Malt extract...... & & & 100 & 99 \\
\hline $\begin{array}{l}\text { A. niger } \\
B, \text { mesentericus }\end{array}$ & 100 & 98 & 96 & 57 to 72 \\
\hline $\begin{array}{l}\text { B. mesentericus } \\
\text { A. oryzae-A. }\end{array}$ & $\begin{array}{r}100 \\
100\end{array}$ & $\begin{array}{l}99 \\
99\end{array}$ & & $\begin{array}{l}65 \\
76\end{array}$ \\
\hline Pancreas & tov & 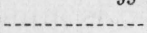 & 84 & 72 \\
\hline Wheat $\beta$-amylase & 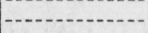 & (2) & - & 102 \\
\hline $\begin{array}{l}\text { Soybean } \beta \text {-amylase } \\
\text { Kaffir malt }\end{array}$ & 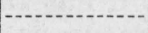 & - n & (n........... & 101 \\
\hline Kaffir malt & & & & \\
\hline
\end{tabular}

1s For discussion of this influence of calcium ions and of the previous literature, see E. Kneen, R. M. Sandstedt, and C. M. Hollenbeck, Cereal Chem. 20399 (1943). 


\section{Journal of Research of the National Bureau of Standards}

kaffir malt, the emulsins made from cereals were also inactive with respect to maltose solutions. However, the enzymes in fungal (Aspergillus), bacterial (B. mesentericus), and pancreatic emulsins produced considerable unfermentable material from maltose. In the presence of the enzymes and yeasts, the material produced by the action of the fungal enzymes is reconverted into fermentable material, but that formed by the bacterial and pancreatic enzymes is only partially reconverted. It should be noted that the figures given in table 3 (except those near 100 percent) are subject to much variation in individual experiments, presumably because of the slow rate of attainment of equilibrium conditions.

As far as is known, the synthesizing action of amylase preparations on maltose has not been previously recorded. It is interesting that similar action does not take place for dextrose solutions, particularly since most of these enzyme preparations contain $\alpha$-glucosidases (maltases). In another respect, however, this synthesis is not surprising, since there are reports of the synthesizing action of bacteria, molds, and the corresponding enzyme preparations on sugar solutions. Thus, Tarr and Hibbert ${ }^{16}$ have reported numerous examples of the synthesis of dextrans and levans by such agents. Also this synthesizing action undoubtedly is the explanation for the results of Stark, ${ }^{17}$ who has studied the composition of the products of the action of pancreatic and salivary amylases on starch substances. According to the results which she reports, there is a continual shift in the nature of the products of hydrolysis, and there are more unfermentable dextrins in the later stages of the reaction than in the intermediary stages. As shown by the results in table 3 , there can be little doubt but that the increase in dextrins observed by Stark is due to a synthesizing action by enzymes.

The fungal, bacterial, and pancreatic emulsins, which exhibit the synthesizing action, are mixtures of enzymes. As a result, it is impossible at the present time to ascribe the observed synthetic action only to the amylase components. The production of unfermentable material may be due to the amylases, but it also may be due to other enzymes, such as those which form the levans and dextrans from sugar solutions. In addition, it should be noted that these experiments were all carried out in the presence of phosphate buffers, and it is quite possible that the formation of unfermentable material may be due to the presence of phosphorylases, which are known to occur in many plant and animal extracts. It is hoped that it will be possible to continue this phase of the investigation in order that additional information may be obtained concerning the nature of the products synthesized and the enzymes which are responsible for the action.

\section{APPLICATION OF BACTERIAL AND PANCREATIC EMULSINS FOR THE LIQUEFACTION OF CORN STARCH}

If a 15-percent corn-starch suspension is heated at $74^{\circ}$ to $78^{\circ} \mathrm{C}$ for a short time, a rigid gel forms. However, if a malt or a bacterial amylase preparation is added to the solution after it has commenced to thicken but before gelation has taken place, the solution rapidly thins; and even if the temperature is raised above $80^{\circ} \mathrm{C}$, gel formation will not take place. This type of procedure has been employed in

\footnotetext{
${ }_{10}$ H. L. A. Tarr and H. Hibbert, Can. J. Research 5, 414 (1931).

17 I. E. Stark, J. Biol. Chem. 142, 569 (1942).
} 
industrial processes for the preparation of grain alcohol and is known as "premalting." However, as carried out industrially with malt, the process is rather inefficient, since the malt usually is mixed with the grains and then heated. The method used in the present work requires the addition of the liquefying amylase after the starch granules are swollen and partially dissolved and is a more efficient procedure. This method is the one described in the introduction and used in the experiments described in table 1. As shown there, when malt is used as the liquefying agent and subsequently as the saccharifying agent, complete conversion to fermentable substances takes place in the presence of yeasts.

The heat stability of certain types of bacterial amylases, notably those of Bacillus mesentericus emulsins, suggests their application in place of malt for the liquefaction of starches under such conditions that gelation will not take place. As previously noted, however, these enzymes are not suitable for the final saccharification of starches since the conversion is not complete in the presence of yeasts. It seemed possible that they might be applied as liquefying agents in conjunction with the use of malt or fungal amylases for the final saccharification. In order to test this possible application, corn starch was treated by the procedure outlined in the introduction except that bacterial amylases were used in the preliminary liquefaction stage. For the final conversion, malt or Aspergillus amylase was employed. In some experiments, the liquefying amylase was also present during the final hydrolysis, but usually it was destroyed by heat inactivation before the malt or fungal enzyme was added. In order to accentuate the action of the liquefying amylases, in certain experiments they were allowed to act on the starches for an additional several days at $57^{\circ} \mathrm{C}$ before they were destroyed and the saccharifying agent was added. Similar experiments were also carried out in which a pancreatic amylase preparation was used as the liquefying agent. The results are recorded in table 4.

\section{TABLE 4.-Action of amylase mixtures on corn starch}

[An amylase preparation is used for liquefaction of the starch. The solution is then heated at $100^{\circ} \mathrm{C}$ (enzyme destroyed.). The solution is then cooled to $45^{\circ} \mathrm{C}$ and one or more amylase preparations added. After several hours, the solutions are cooled and yeasts added.]

\begin{tabular}{|c|c|}
\hline Amylases and conditions employed in experiments & $\begin{array}{l}\text { Conversion to } \\
\text { fermentable } \\
\text { substances in } \\
\text { the presence of } \\
\text { yeasts (percent- } \\
\text { age of theoret- } \\
\text { ical) }\end{array}$ \\
\hline $\begin{array}{l}\text { 1. (a) B. mesentericus emulsin used for liquefaction. Malt } \\
\text { usedfor final conversion. } \\
\text { (b) B. mesentericus emulsin used for liquefaction. B. mesen- } \\
\text { tericus emulsin added with the malt in the final conversion. } \\
\text { (c) B. mesentericus emulsin used for liquefaction. A or yzae } \\
\text { emulsin used for final conversion. } \\
\text { 2. (a) Pancreas emulsin used for liquefaction. Malt used for } \\
\text { final conversion. } \\
\text { (b) Pancreas emuslin used for liquefaction. Pancreas and } \\
\text { malt present during final conversion. } \\
\text { 3. Pancreas and } B \text {. mesentericus emulsins used together in both } \\
\text { stages. }\end{array}$ & $\begin{array}{r}91 \\
\text { b81 } \\
91 \\
98 \\
\text { b90 } \\
85 \\
\text { b77 } \\
85 \\
\\
\text { b79 }\end{array}$ \\
\hline
\end{tabular}

- A pH of about 5 , as employed in the final conversion, is unfavorable for the action of the B. mesentericus and pancreas enzymes.

b The liquefaction period was extended to several days in order to provide good opportunity for synthesizing action. 


\section{Journal of Research of the National Bureau of Standards}

It is evident from the results outlined in table 4 that the joint use of the bacterial emulsin in conjunction with malt amylases leads to an appreciable loss of fermentable material. This loss is particularly evident for the experiments in which the liquefying amylase remains in contact with the starch for a considerable time. Even for short periods of action there is an appreciable loss of fermentable substance. The Aspergillus emulsin, however, appears to have a greater ability than the malt in reconverting unfermentable material to fermentable substance. The results obtained for the bacterial emulsin are paralleled by those obtained by use of the pancreatic emulsin as the liquefying agent. It should be noted that the results in table 4 should be considered as representative results without much absolute significance; the values obtained will depend on the particular conditions selected for the measurements, since equilibrium conditions are not attained.

These experiments show that the application of bacterial and pancreatic agents for the liquefaction of starches may be a source of loss of considerable quantities of fermentable material, particularly if their action takes place for a considerable time, or if malt is employed as the saccharifying agent. Such agents would have to be used with considerable caution if employed for the preparation of grain alcohol. For other purposes, however, such as the preparation of sizes and adhesives, this behavior should not be objectionable and might even be advantageous.

\section{ACTION OF AMYLASE PREPARATIONS ON THE UN- FERMENTABLE RESIDUAL DEXTRINS}

In order to provide information concerning the unfermentable fraction produced by the various types of amylase preparations from starch, the action of enzymes on the residual dextrins was investigated. For these experiments, the enzymes were allowed to act on corn starch for several days at $57^{\circ} \mathrm{C}$ (first conversion), and the fermentable material was removed by yeasts, usually in the absence of the original amylases. The alcohol was distilled from the mixture, and the residue (which contained the unfermentable material) was treated again with an enzyme preparation (second conversion). Finally, yeasts were added, and the amount of fermentable substance formed by the action of the enzymes on the residual dextrins was calculated from the quantity of alcohol produced. The results obtained are summarized in table 5 .

TABLE 5.-Action of enzymes on unfermentable material produced from corn starch by malt, pancreas, and $B$. mesentericus enzymes

\begin{tabular}{|c|c|c|c|}
\hline \multicolumn{2}{|c|}{ First conversion } & \multicolumn{2}{|l|}{ Second conversion } \\
\hline Amylase preparation & $\begin{array}{c}\text { Unfer- } \\
\text { mentable } \\
\text { material } \\
\text { remaining }\end{array}$ & Amylase preparation & $\begin{array}{c}\text { Unfer- } \\
\text { mentable } \\
\text { material } \\
\text { remaining }\end{array}$ \\
\hline $\begin{array}{l}\text { B. mesentericus } \\
\text { Do } \\
\text { Do } \\
\text { Do } \\
\text { Pancreas.-. } \\
\text { Do } \\
\text { Do } \\
\text { Malt extract-a. } \\
\text { Do }\end{array}$ & $\begin{array}{l}\text { \% } \\
30 \\
32 \\
45 \\
46 \\
19 \\
17 \\
17 \\
10 \\
10\end{array}$ & $\begin{array}{l}\text { B. mesentericus. } \\
\text { A. oryzae } \\
\text { A. oryzae } \\
\text { Malt.. } \\
\text { Pancreas. } \\
\text { A. oryzae } \\
\text { Malt } \\
\text { Malt (in absence of yeasts) } \\
\text { Malt (in presence of yeasts) }\end{array}$ & $\begin{array}{r}\% \\
28 \\
12 \\
14 \\
20 \\
19 \\
17 \\
17 \\
4 \\
4\end{array}$ \\
\hline
\end{tabular}


7 Residual dextrins from action of malt amylases on corn starch.-As mentioned in the discussion of table 2, the malt enzymes are capable of converting starches to fermentable material to an extent of about 90 percent (in the absence of yeasts). This action was ascribed to the $\alpha$-amylase constituent, since the same degree of conversion was attained by the use of the kaffir malt, which is reported to be devoid of $\beta$-amylase activity. The unfermentable material, by application of the procedure summarized above, was treated a second time with a malt extract subsequent to the removal of the fermentable material by fermentation. After the second treatment the enzyme was destroyed by heat inactivation. Considerable fermentable material was produced by this second enzyme treatment. In fact, the quantity was the same as that produced when malt enzymes and yeast were allowed to act together in the second treatment. These results indicate strongly the existence of an equilibrium between the unfermentable and the fermentable material. The equilibrium mixture appears to contain about 90 percent of fermentable and 10 percent of unfermentable sugars.

In the experiments previously mentioned (see discussion of table 3 ), the malt amylases were not able to synthesize unfermentable material from maltose. Apparently then, the equilibrium mixture produced from starch must contain fermentable materials, other than maltose, which are necessary for the establishment of the equilibrium. In agreement with this conclusion, it has already been established ${ }^{18}$ that such mixtures also contain dextrose, trisaccharides, etc.

Residual dextrins from the action of bacterial and pancreatic emulsins on corn starch.-The fermentable material remaining from the action of $B$. mesentericus or pancreas emulsin on corn starch (after removal of fermentable material) was given a second treatment with the same enzymes. However, in neither case was any additional fermentable sugar formed. These results differ from those obtained by the action of malt enzymes on the unfermentable material resulting from the action of malt, as mentioned above. It would seem that the action of the bacterial and pancreatic emulsins does not involve a true equilibrium.

Although the unfermentable material produced by the action of pancreatic enzymes appears to be resistant to attack by both malt and Aspergillus oryzae enzymes, that formed by the bacterial enzymes is reconverted to fermentable substance to a considerable extent by both the malt and Aspergillus enzymes. The bacterial emulsins formed more unfermentable material than the pancreatic emulsins; it is of interest that after the secondary action of malt or Aspergillus enzymes, the total amount of fermentable material is approximately the same and is independent of the amylase type originally used (pancreas or $B$. mesentericus amylases). It does appear, however, that the Aspergillus oryzae enzymes are able to bring about a greater reconversion to fermentable substances than the malt enzymes.

\section{NATURE OF ACTION AND CLASSIFICATION OF THE AMYLASES}

The results obtained in this investigation agree with the present views of the action of $\beta$-amylases. As mentioned in the discussion of table 2, the amount of fermentable material produced from corn and

s8 K. Myrbäck, J. prakt. Chem. 162, 29 (1943); I. Stark, J. Biol. Chem. 142, 569 (1942). 


\section{Journal of Research of the National Bureau of Standards}

waxy maize starch by $\beta$-amylases appears to be the same in the presence or absence of yeasts; it also quantitatively agrees with the amount of reducing sugar obtained by most earlier workers and calculated as maltose. According to the accepted views, $\beta$-amylase action takes place by the successive removal of maltose residues from the ends of continuous straight chains of maltose residues. The action stops when some special type of linkage (other than the maltose alpha $1,4^{\prime}$ type, and possibly of the $1,6^{\prime}$ type) is encountered. The remaining material is believed to consist of a high molecular weight dextrin which resists the action of $\beta$-amylases and yeasts.

The nature of the action of liquefying amylases is less clearly established but is known to lead to the production of reducing dextrins mainly with 4 to 12 glucose residues per molecule. According to the previous work, the action must take place over or at the linkages which stop the action of the $\beta$-amylases, and there is no high molecular weight dextrin fraction. According to Hanes ${ }^{19}$ and to Myrbäck, ${ }^{20}$ the enzymic hydrolysis proceeds through the primary liberation of fragments containing about six glucose residues. These fragments subsequently may be broken down into shorter chains. The liquefying amylases which may operate in this manner are those which occur in pancreas, saliva, certain bacteria, fungus, and many cereal (particularly malted cereals) enzyme preparations. As a group, the amylases in these emulsins have been known as $\alpha$-amylases.

The results obtained in the present investigation, discussed above in connection with table 2 , indicate that there may be a fundamental difference in action between the various liquefying amylases. Thus, the cereal liquefying enzymes and the Aspergillus enzymes are able to break down starches completely to fermentable sugars in the presence of yeasts. The pancreas and Bacillus mesentericus enzymes, although they exhibit marked liquefying ability, do not appear to be able to accomplish the complete saccharification of starches to fermentable sugars in the presence of yeasts. It may be that the latter group of enzymes act similarly to the liquefying Bacillus macerans amylase. This enzyme is known to act with the production of cyclic hepta and hexasaccharides (Schardinger dextrins) ${ }^{21}$; but it is not established whether the formation of these materials is a primary action or is a result of secondary resynthesis from the products of hydrolysis. The synthesis of unfermentable materials from maltose by the pancreas and $B$. mesentericus enzymes suggests that it may be desirable to carry out such experiments with the $B$. macerans enzymes. However, until additional work has been carried out, it appears wise to separate the liquefying amylases into two main groups:

Group 1: Cereal $\alpha$-amylases and Aspergillus amylases.

Group 2: Pancreas, and B. mesentericus amylases. Probably, also salivary and B. macerans amylases.

Until further information is available, it might be wise to reserve the term " $\alpha$-amylases" for the liquefying cereal amylases.

19 C. S. Hanes, New Phytologist 36, 101, 189 (1937).

20 K. Myrbäck, J. prakt. Chem. 162, 29 (1943).

21 D. French and R. E. Rundle, J. Am. Chem. Soc. 64, 1651 (1942); W. S. McClenahan, E. B. Tilden, and C. S. Hudson, J. Am. Chem. Soc. 64, 2139 (1942); F. Schardinger, Zentr. Bakt. Parisitenk. [2], 22, 98 (1908); R. W. Kerr, J. Am. Chem. Soc. 64, 3044 (1942); E. J. Wilson, Jr., T. J. Schoch and C. S. Hudson 65, 1380 (1943). 


\section{VIII.EXPERIMENTAL PROCEDURE}

\section{MATERIALS USED}

(a) ENZYME PREPARATIONS (EMULSINS)

The Aspergillus niger, Aspergillus oryzae, Bacillus mesentericus and whole pancreas emulsins were active commercial preparations supplied through the courtesy of the Wallerstein Laboratories (New York, N. Y.), the Schwarz Laboratories (New York, N. Y.), and the Rohm $\&$ Haas Co. (Philadelphia, Pa.). Their properties have been previously described. ${ }^{22}$

The malt extract, wheat $\beta$-amylase and malt $\alpha$-amylase preparations were special emulsins supplied through the courtesy of the Wallerstein Laboratories. The malt extract and wheat $\beta$-amylase have been previously described and were made by extraction and salt precipitation of the extracts. For the preparation of the malt $\alpha$-amylase, the heat inactivation procedure of Ohlsson ${ }^{23}$ was used. It is known that such treatment does not completely remove all $\beta$-amylase. The kaffir malt (germinated Sorghum vulgare) was supplied through the courtesy of Eric Kneen, of the University of Nebraska. According to the literature ${ }^{24}$ it contains only an $\alpha$-amylase. The malt sample employed was a commercial (Pabst) distillers' barley malt with a Lintner value of $188^{\circ}$ (dry basis).

Soy bean $\beta$-amylase was prepared by the general procedure of Newton and Naylor. ${ }^{25}$ Palmetto and Missoy varieties were employed and were supplied through the courtesy of W. J. Morris of the Bureau of Plant Industry (U. S. Department of Agriculture, Beltsville, Md.). Several improvements ${ }^{26}$ in the published procedure have simplified the process and have increased the yields. Best results were obtained by the following procedure:

The ground beans are placed in a percolator and extracted with acetone until the extracts are colorless. The extraction requires about 2 days, and the rate of flow is about 3 drops per second. The defatted beans are then allowed to dry at room temperature. From 1,800 $\mathrm{g}$ of original beans, about 1,300 $\mathrm{g}$ of defatted meal are obtained.

For the extraction of the $\beta$-amylase, $800 \mathrm{~g}$ of the defatted beans is treated with $3,200 \mathrm{ml}$ of 50 -percent ethyl alcohol containing $1.6 \mathrm{~g}$ of sodium sulfite. (The solution is made by mixing $1,700 \mathrm{ml}$ of 95 -percent ethyl alcohol, $1,530 \mathrm{ml}$ of water, $1.6 \mathrm{~g}$ of sulfite, and enough glacial acetic acid to bring the $\mathrm{pH}$ to about 6 or 7 .) The mixture is allowed to stand for 3 hours at room temperature, and during this time it is shaken at frequent intervals. The solution is filtered through coarse paper on a Büchner funnel; the residue is washed with about $500 \mathrm{ml}$ of 50 -percent alcohol; and the washings are added to the original extracts. The extracts are placed in a glass jar (surrounded by an ice bath and equipped with a mechanical stirrer) and cooled to $0^{\circ} \mathrm{C}$. Enough 95 -percent alcohol is added to the stirred solution (slowly from a separatory funnel) to bring the total alcohol concentration to 65 percent by volume. (If the above volumes have been used, $1,870 \mathrm{ml}$ of 95-percent alcohol may be added.) The precipitated material is allowed to settle for 15 to 30 minutes. The supernatant liquid, which contains but little active $\beta$-amylase, is poured off and discarded. The gummy precipitate is covered with acetone for a few minutes. The acetone is poured off and more added. (Pouring off and not filtration is recommended at this stage as the acetone extracts filter very slowly.) This process is repeated several times and the gum, which rapidly hardens, is powdered with the aid of a spatula The powder finally is separated by filtration, and after removal of the acetone it is kept over calcium chloride in

22 W. W. Pigman, J. Research NBS 30, 159 (1943) RP 1526.

23 E. Ohisson, Z. physiol. Chem. 189, 17 (1930).

24 E. Kneen, Wallerstein Comm. 6, 101 (1943).

25 J. M. Newton and N. M. Naylor, Cereal Chem. 16, 71 (1939).

26 The assistance of Mary Grace Blair in carrying out this preparation is gratefully acknowledged. 


\section{Journal of Research of the National Bureau of Standards}

a refrigerator. The yield of material ranges from 0.9 to 1.2 percent of the weight of the defatted beans. Newton and Naylor reported yields of 0.3 to 0.5 percent by their original procedure. The activity of the various preparations obtained by the above procedure fell between the limits 2,400 to $3,400^{\circ} L .^{27}$

\section{(b) STARCHES}

The commercial corn starches used in the present investigation were supplied by the Clinton Co. (Clinton, Iowa) and the Corn Products Refining Co. (Argo, Ill.). The wheat starch was an experimental sample prepared from Rex, soft, white wheat and supplied through the courtesy of Cecil T. Langford, of the Northern Regional Research Laboratory (U. S. Department of Agriculture). The potato starch was a commercial sample provided by the Corn Products Refining Co., and the samples of waxy maize starch originated from the National Starch Products (New York, N. Y.) and the American Maize-Products Co. (New York, N. Y.). Merck "soluble starch according to Lintner" was purchased.

The procedure of Schoch (see reference on page 108) was employed for the preparation of the amylose from potato starch. By the introduction of certain minor changes it was possible to simplify the procedure somewhat; in the modified procedure, filtration of the amylase is possible rather than centrifugation. The procedure used follows:

A stirred suspension of $40 \mathrm{~g}$ of starch in 2 liters of water contained in a beaker is heated to boiling. After $400 \mathrm{ml}$ of $n$-butanol is added, the beaker is placed in an autoclave and heated for 2 hours at a pressure of $20 \mathrm{lb} / \mathrm{in}^{2}$. The autoclave is opened as soon as possible, and a mixture of $100 \mathrm{ml}$ of butanol and $100 \mathrm{ml}$ of isoamyl alcohol is added. The beaker is removed, covered with a watch glass, insulated carefully by wrapping well with a thick layer of cloth, and allowed to cool slowly to about $50^{\circ} \mathrm{C}$ for 24 to 48 hours. Subsequently, the temperature is allowed to drop to room temperature over a period of 24 to 48 hours. The rate of cooling to $50^{\circ} \mathrm{C}$ appears to be quite important; if it is too rapid the amylase fraction will appear as a gelatinous layer rather than as fine but discrete particles. The amylose fraction may be separated easily by filtration through a Buchner funnel covered first with a piece of filter cloth and then with a piece of hardened paper. However, the suspensions frequently contain a small quantity of gelatinous material which may cover the paper and prevent filtration. To avoid this difficulty, it is necessary to remove the interfering material. Since most of it appears in the original suspension as a scum between the aqueous phase and the supernatant alcohol phase, it should be carefully removed by decantation or by skimming with a spoon. In any case, if the filtration becomes too slow, it may be hastened by occasional scraping of the filter surface with a spatula. When the most of the mother liquor has been removed from the crystals, the wet mass is washed well several times with butanol-saturated water and finally several times with methanol.

The moisture content of the various starches were determined by drying them to constant weight in a vacuum at $90^{\circ} \mathrm{C}$ over calcium chloride. The values lay between 11 and 13 percent for waxy maize and corn starch; that for the soluble starch fell in the range 8 to 10 percent. The amylose had a moisture content of 2.5 percent. In all of the experiments in which these materials were employed for quantitative determinations, allowance was made for the moisture content A few experiments were carried out with methanol-extracted starches, but as no significant difference from the commercial starches could be observed, the commercial products were employed.

\section{PROCEDURES}

In preliminary work, numerous experiments were carried out in order to establish the best conditions for the liquefaction and sub-

\footnotetext{
${ }^{27}$ Cereal Laboratory Methods, Am. Assn. Cereal Chemists, Lincoln, Nebr., 1941.
} 
sequent saccharification of the starches. Because of the variable heat resistance and optimal $\mathrm{pH}$ of the enzymes, no single procedure could be used. However, the procedures given below can be employed in most instances or can be modified slightly to provide the best conditions. The general applicability of these procedures is demonstrated by the production of alcohol in theoretical yields. Theoretical, in this case, means the amount of alcohol that is formed from an equivalent quantity of dextrose under the same conditions. Considerable work was carried out in order to determine the best conditions for the fermentation of maltose and dextrose These experiments are described in another publication, ${ }^{28}$ in which it is shown that under the conditions employed here, the presence of nutrients have no influence on the alcohol yields and that the fermentation efficiency as calculated from the Gay-Lussac equation is close to 88.5 percent for dextrose and for maltose.

\section{PROCEDURE FOR RELATIVELY HEAT-STABLE ENZYMES WHICH OPERATE WELL AT A pH OF ABOUT 5.0}

Liquefaction step.-Weigh out accurately $24.96 \mathrm{~g}$ of starch (dry basis) into a $500-\mathrm{ml}$ round-bottomed flask a (see notes below.) Add $125 \mathrm{ml}$ of water and 40 $\mathrm{ml}$ of buffer solution $\mathrm{b}(\mathrm{p} \mathrm{H}, 5.2)$. Shake flask until all the starch is suspended and not clumped. Place flask in a water bath, ${ }^{\circ}$ and stir contents with the aid of mechanical stirrer. Heat water bath to $74^{\circ}$ to $76^{\circ} \mathrm{C}$ and keep at this temperature until the solution thickens appreciably or for about 10 minutes. Add a slurry of $0.5 \mathrm{~g}$ of malt extract (or $2 \mathrm{~g}$ of ground barley malt) in 10 $\mathrm{ml}$ of water to the flask, and use a little water to wash the enzyme preparation into the flask. Remove flask from bath and shake gently with a rotatory motion in order to work the enzyme into the partially pasted solution. Replace in bath, and stir contents for about 10 minutes at a temperature of about $70^{\circ}$ to $72^{\circ} \mathrm{C}$. Again remove flask from bath, and inspect in order to make sure that no lumps are present, particularly on the sides of the flask. If lumps are found, work them off by gentle manual rotation of the flask and contents. Then, replace the flask in the bath and stir mechanically.

"Cooking" step.- Raise the temperature of the bath to $100^{\circ} \mathrm{C}$ and hold at this temperature for 30 minutes. Remove flask from bath, stopper with sterile cotton, and place in a new water bath in which the temperature is regulated between $45^{\circ}$ and $50^{\circ} \mathrm{C}$.

Conversion or saccharification step.-To the "cooked" starch solution at a temperature of $45^{\circ}$ to $50^{\circ} \mathrm{C}$, add $1.0 \mathrm{~g}$ of malt extract (or $3 \mathrm{~g}$ of ground malt). Keep solution in the bath for at least 1 hour. Then remove and allow to cool to $30^{\circ} \mathrm{C}$ or less.

Fermentation step.-To the enzyme-treated solution, add 5 or $6 \mathrm{~g}$ of compressed bakers' yeast and 1 to $2 \mathrm{~g}$ of sterile potassium citrate. Close the flask with a stopper carrying a glass tube which is bent so that the liberated carbon dioxide may be discharged under water. Allow the solution to ferment for 5 days at about $30^{\circ} \mathrm{C}$, and during this time shake flask twice each day.

Determination of alcohol.- At the conclusion of the fermentation, remove stopper and wash any adhering liquid into the flask. Connect the flask to a condenser. Distill almost $100 \mathrm{ml}$ into a $100-\mathrm{ml}$ volumetric flask. Place the flask containing the distillate in a constant temperature bath and make carefully to volume. Weigh the flask and contents, calculate the density, and from proper tables calculate the yield of alcohol. For details of these calculations and precautions that must be exercised, see the previously mentioned paper. ${ }^{28}$

\section{NOTES}

(a) Round-bottomed flasks were found more desirable for this step than commercial Florence flasks because the neck diameters are larger. For routine work, it was found desirable to flatten the bottoms of such flasks so that they could be kept in the incubator without a supporting ring.

${ }^{28}$ M. G. Blair and W. W. Pigman (manuscript pending). 
- (b) The buffer solution was prepared by dissolving the following quantities of substances in water and making to a volume of 1 liter:

$$
\begin{aligned}
40 \mathrm{~g} \mathrm{NH} \mathrm{NH}_{2} \mathrm{PO}_{4} & \mathrm{NH}_{2} \mathrm{~g} \mathrm{~K} \mathrm{HOO}_{4} .3 \mathrm{H}_{2} \mathrm{O} \\
28 \mathrm{~g} \mathrm{KH} & \mathrm{KO}_{4} .
\end{aligned}
$$

(c) As a water bath for the liquefaction and cooking steps, a pan of water heated with a gas flame was found to be satisfactory and to be capable of good temperature regulation.

Modifications of procedure.-Certain types of amylases are destroyed too rapidly at $70^{\circ} \mathrm{C}$ to be employed in the above procedure. To this group belong the fungal, pancreatic, and probably the soybean and wheat amylases. When it is desired to test these enzymes, the procedure need only be modified slightly in the liquefaction step. Thus, after the starch suspension has been allowed to partially gelatinize, it is cooled rapidly to $50^{\circ} \mathrm{C}$, and the enzyme is added and allowed to act for 15 to 30 minutes at this temperature. Then the solution is heated to $78^{\circ}$ over a period of about 15 minutes, and finally rapidly to $100^{\circ} \mathrm{C}$.

Some variations in the procedure.-For some enzymes it is desirable to carry out the reaction at a lower acidity than is most favorable for the malt and fungal enzymes. Thus, the Bacillus mesentericus and the pancreatic amylases have their optimal $\mathrm{pH}$ near $\mathrm{pH} 6$ to 7 . It is not desirable to maintain the $\mathrm{pH}$ at 6 to 7 during the cooking procedure, however, as an appreciable loss of fermentable sugars would result. In the experiments described in the present paper, the liquefaction and cooking steps were carried out at a $\mathrm{pH}$ of about 5.2. For the bacterial and pancreatic enzymes, $17 \mathrm{ml}$ of $N$ potassium hydroxide solution was added with the enzyme in the saccharification step. This quantity of alkali brings the $\mathrm{pH}$ to about 7.0 .

The slight liquefying power of $\beta$-amylase preparations necessitates extension of the saccharification period to about 24 hours. In order to prevent the growth of micro-organisms during this period, it may be desirable to maintain the temperature at $57^{\circ}$ to $60^{\circ} \mathrm{C}$. If the higher temperatures are used, a fresh portion of the $\beta$-amylase should be added with the yeast in the final fermentation step. Such solutions also tend to foam badly during the fermentation and during the subsequent distillation of the alcohol.

A number of experiments were carried out in which the amylase was destroyed before the yeast was added. For these experiments it was necessary to keep the solutions for a considerable period in the presence of the amylases; this was accomplished by extending the saccharifying period to several days. Originally, considerable difficulty was encountered in preventing the growth of molds and bacteria during this time. However, by keeping the temperature at $50^{\circ} \mathrm{C}$ for 3 to 6 hours and then raising it to $57^{\circ} \mathrm{C}$ and keeping it at $57^{\circ} \mathrm{C}$, growth of microorganisms could be prevented. Since some of these enzymes may be destroyed at $57^{\circ} \mathrm{C}$, a fresh portion of the enzyme preparation was added each day during the saccharification step. After several days, the solutions were heated at $100^{\circ} \mathrm{C}$ for 15 to 30 minutes in order to inactivate the enzyme. Finally, the solution was cooled and the yeast was added.

Washington, May 23, 1944. 